\title{
Cellular mechanisms of growth inhibition of human endometrial cancer cell line by an antagonist of growth hormone-releasing hormone
}

\author{
LIN ZHAO $^{1}$, TETSU YANO ${ }^{1}$, YUTAKA OSUGA ${ }^{1}$, SHUNSUKE NAKAGAWA ${ }^{1}$, \\ HAJIME OISHI $^{1}$, OSAMU WADA-HIRAIKE ${ }^{1}$, XIAOHUI TANG ${ }^{1}$, NAOMI YANO ${ }^{1}$, \\ KOJI KUGU ${ }^{1}$, ANDREW V. SCHALLY ${ }^{2}$ and YUJI TAKETANI ${ }^{1}$
}

\begin{abstract}
${ }^{1}$ Department of Obstetrics and Gynecology, Faculty of Medicine, The University of Tokyo, Tokyo 113-8655, Japan;
${ }^{2}$ Endocrine Polypeptide and Cancer Institute, Veterans Affairs Medical Center and South Florida Veterans Affairs Foundation for Research and Education and Departments of Pathology and Medicine, Division of Hematology/

Oncology, University of Miami Miller School of Medicine, Miami, FL 33125, USA
\end{abstract}

Received September 12, 2007; Accepted November 19, 2007

\begin{abstract}
The expression of growth hormone-releasing hormone (GHRH) and its receptors has been demonstrated in peripheral tissues as well as CNS. Recently, the functional splice variant SV1 of GHRH receptor was identified in various human cancers and cancer cell lines. Although antineoplastic activity of GHRH antagonists has been clearly demonstrated, the mechanism of action is incompletely understood. The objective of this study was the investigation of direct antiproliferative effect of GHRH antagonist MZ-5-156 on HEC-1A human endometrial cancer cell line and the elucidation of underlying mechanisms. RT-PCR revealed the expression of mRNA for GHRH and SV1 of GHRH receptor in HEC-1A cells. MZ-5-156, at concentrations between $10^{-7}$ and $10^{-5} \mathrm{M}$, had a dose-dependent antiproliferative effect on HEC-1A cells, as determined by 3-(4,5-dimethylthiazol-2-yl)-5-(3carboxymethoxyphenyl)-2-(4-sulfophenyl)-2H-tetrazolium, (MTS) assay. Hoechst 33342 staining and flow cytometric analysis indicated that MZ-5-156, at $10^{-6} \mathrm{M}$, induced apoptosis in HEC-1A cells after $48 \mathrm{~h}$ of treatment. Western blot analysis of apoptosis-related proteins demonstrated that treatment with MZ-5-156 $\left(10^{-6} \mathrm{M}\right)$ for $48 \mathrm{~h}$ significantly increased the protein levels of Fas, phospho-p53 (Ser46), p53AIP1 (p53-regulated Apoptosis-Inducing Protein 1), and caspase-8, -9 , and -3 , and decreased the protein level of Bcl-2. These results demonstrate that MZ-5-156 can directly inhibit the
\end{abstract}

Correspondence to: Dr Tetsu Yano, Department of Obstetrics and Gynecology, Faculty of Medicine, The University of Tokyo, 7-3-1 Hongo, Bunkyo-ku, Tokyo 113-8655, Japan

E-mail: tetu-tky@umin.ac.jp

Key words: growth hormone-releasing hormone antagonist, endometrial cancer, apoptosis, p53 proliferation of human endometrial cancer cells, which express mRNA for GHRH and SV1 of GHRH receptor, presumably through the induction of p53-dependent apoptosis coupled with the up-regulation of Fas, phospho-p53 (Ser46), p53AIP1, and caspase- $8,-9$, and -3 , and the down-regulation of Bcl-2.

\section{Introduction}

Endometrial cancer is one of the most common malignancies of the female genital tract. In the US, approximately 40,000 new cases of endometrial cancer are expected to be diagnosed in 2007, with an estimated 7,000 deaths (1). Surgery, radiation, chemotherapy, and endocrine therapy with progestin are of limited effectiveness in the treatment of advanced and disseminated endometrial cancer, and new therapeutic approaches are needed (2).

Growth hormone-releasing hormone $(\mathrm{GHRH})$ is secreted by the hypothalamus and upon binding to GHRH receptor (GHRH-R) in the pituitary, stimulates the synthesis and the release of $\mathrm{GH}$. GH, in turn, induces the production of hepatic insulin-like growth factor I (IGF-I) $(3,4)$. IGF-1 is a known mitogen for various cell types and has been linked with malignant transformation, tumor progression, and metastasis of diverse cancers (5). Since 1994, numerous GHRH antagonists including MZ-5-156 have been synthesized in the laboratory of one of us (Andrew V. Schally) for therapeutic use in the management of various malignancies $(3,4)$. These GHRH antagonists were found to inhibit the growth of human ovarian, endometrial, breast, prostatic, colorectal, pancreatic, renal, and lung cancer, osteosarcoma, and non-Hodgkin's lymphoma xenografted into nude mice $(3,4,6,7)$. In vitro and in vivo studies revealed that GHRH antagonists can inhibit tumor growth through indirect and direct pathways. The indirect mechanism is based on the suppression of the pituitary GH/hepatic IGF-I axis. Thus, GHRH antagonists, by blocking the pituitary GHRH-R, can inhibit the synthesis and release of $\mathrm{GH}$, with the resulting reduction in hepatic IGF-I production. However, much evidence indicates that the principal anti- 
proliferative effects of GHRH antagonists are probably exerted directly through the blocking of the stimulatory loop formed by tumoral GHRH and its receptors on tumors, and by the disruption of the autocrine/paracrine production of IGF-I and/or IGF-II on tumors $(3,4,8,9)$. The isolation and sequencing of cDNAs corresponding to the tumoral GHRH-R mRNAs revealed that they are truncated splice variants (SVs) of the pituitary GHRH-R (10). The presence of four SVs of GHRH-R has been demonstrated in various human cancers and cancer cell lines $(6,7,9,10-17)$. Of the four isoforms, SV1 of GHRH-R has the greatest structural similarity to the pituitary GHRH-R and is probably the main SV that mediates the effects of GHRH and its antagonists in tumors (18-20).

The cellular mechanisms involved in the antiproliferative effects of GHRH antagonists on tumor cells have not yet been completely elucidated. Recent studies have shown that, in addition to cAMP, other intracellular second messengers, such as PKC, MAPK, and c-fos and c-jun oncogenes, may participate in the signal transduction pathways of GHRH antagonists mediated by tumoral GHRH-R (16,21-23). It has also been reported that GHRH antagonists induce apoptosis in LNCaP human prostate cancer cell line through the elevation of intracellular free $\mathrm{Ca}^{2+}$ levels (24). Although GHRH antagonists have been shown to induce apoptosis in human prostate (LNCaP), colon (HT-29), and breast (MDA-MB-231) cancer cell lines and MXT mouse mammary cancer cells, little is known about the exact apoptotic pathway (24-27).

In the previous in vitro and in vivo experiments, GHRH antagonist MZ-5-156 (28) inhibited the growth of human ovarian (OV-1063), breast (MDA-MB-468), prostate (PC-3 and DU-145), and pancreatic (SW-1990 and CAPAN-2) cancer cell lines and non-Hodgkin's lymphoma (RL and HT) cell lines $(6,17,21,29,30)$. In the present study, we investigated the expression of SV1 of GHRH-R in HEC-1A human endometrial cancer cell line and the direct effects of GHRH antagonist MZ-5-156 on the growth of HEC-1A cells, including the induction of apoptosis. In order to elucidate the cellular mechanisms by which MZ-5-156 inhibits cancer cell growth, we also examined the expression of apoptosis-related proteins in HEC-1A cells.

\section{Materials and methods}

Chemicals. GHRH antagonist MZ-5-156 was synthesized by solid phase methods (28). The chemical structure of MZ-5-156 is $\left[\mathrm{PhAc}-\mathrm{Tyr}^{1}, \mathrm{D}-\mathrm{Arg}^{2}\right.$, Phe(4-Cl) $\left.{ }^{6}, \mathrm{Abu}^{15}, \mathrm{Nle}^{27}\right] \mathrm{hGHRH}-$ (1-28)Agm, where $\mathrm{PhAc}$ is phenylacetyl, $\mathrm{Phe}(4-\mathrm{Cl})$ is 4-chlorophenylalanine, $\mathrm{Abu}$ is $\alpha$-aminobutyric acid, Nle is norleucine, and Agm is agmatine (17). DMEM-F12 medium and fetal bovine serum (FBS) were purchased from Invitrogen Corp. (Carlsbad, CA, USA). All other chemicals, unless otherwise mentioned, were obtained from Sigma (St. Louis, MO, USA).

Cell line and cell culture. HEC-1A human endometrial cancer cell line, which originated from a moderately differentiated papillary adenocarcinoma of the endometrium in a 71-year-old Japanese woman (31), was obtained from American Type Culture Collection (Manassas, VA, USA). The cell line was grown in DMEM-F12 medium supplemented with 10\% FBS, $15 \mathrm{mM}$ HEPES buffer, $2 \mathrm{mM}$ glutamine, $100 \mathrm{U} / \mathrm{ml}$ penicillin,
$100 \mu \mathrm{g} / \mathrm{ml}$ streptomycin, and $0.25 \mu \mathrm{g} / \mathrm{ml}$ amphotericin B in a humidified atmosphere of $5 \% \mathrm{CO}_{2}$ and $95 \%$ air at $37^{\circ} \mathrm{C}$.

$R T-P C R$. Total RNA was extracted from cultured HEC-1A cells by the acid guanidinium-phenol-chloroform (AGPC) method using Isogen (Nippongene, Toyama, Japan). First-stand cDNA was synthesized in a reaction volume of $20 \mu 1$ containing $1 \mu \mathrm{g}$ total RNA by using ReverTra Dash (Toyobo, Tokyo, Japan) according to the manufacturer's instructions. After the reverse transcription reaction, cDNA was amplified to determine GHRH and GHRH receptor SV1 expression using the following primer pair: GHRH, 5'-ATGCAGATGC CATCTTCACCAA-3' (sense) and 5'-TGCTGTCTACCTGA CGACCAA-3' (antisense) (GenBank NM021081); GHRH splice variant receptor (SV1), 5'-TGGGGAGAGGGAAGGA GTTGT-3' (sense) and 5'-GCGAGAACCAGCCACCA GAA-3' (antisense) (GenBank AF282259). PCR was carried out with the Takara Taq (Takara Shuzo Co., Ltd., Otsu, Japan) in a DNA thermal cycler (GeneAmp PCR System 9700; Perkin-Elmer Applied Biosystems, Foster City, CA, USA). After an initial denaturation at $95^{\circ} \mathrm{C}$ for $5 \mathrm{~min}$, the samples were submitted to 35 reaction cycles under the following conditions: denaturation for $10 \mathrm{sec}$ at $98^{\circ} \mathrm{C}$, annealing for $2 \mathrm{sec}$ at $60^{\circ} \mathrm{C}$, and extension for $30 \mathrm{sec}$ at $74^{\circ} \mathrm{C}$. PCR amplified products were electrophoresed on a $2 \%$ agarose gel containing $0.5 \mu \mathrm{g} /$ liter ethidium bromide and photographed under UV light. The PCR products were characterized by using a DNA sequencer (ABI PRISM 310 Genetic Analyzer; Perkin-Elmer Applied Biosystems).

Cell viability assay. Cell viability was examined by using the 3-(4,5-dimethylthiazol-2-yl)-5-(3-carboxymethoxyphenyl)-2(4-sulfophenyl)-2H-tetrazolium, inner salt (MTS) assay kit (CellTiter 96 Aqueous One Solution Cell Proliferation Assay; Promega Corp., Madison, WI, USA) according to the manufacturer's instructions. Briefly, HEC-1A cells were seeded into 96-multiwell plates (Becton Dickinson and Co., Franklin Lakes, NJ, USA) at a density of $3 \times 10^{3}$ cells/well in $100 \mu 1$ of the culture medium. After $24 \mathrm{~h}$, the medium was replaced with fresh FBS-free medium. After an additional $24 \mathrm{~h}$, the medium was replaced with fresh medium containing $2 \%$ FBS and various concentrations of GHRH antagonist MZ-5-156, and cell culture was continued for a further 24 or 48 , or $72 \mathrm{~h}$. MZ-5-156 was dissolved in dimethyl sulfoxide and diluted with the medium to yield desired concentrations. The final concentration of dimethyl sulfoxide never exceeded $0.05 \%$. Finally, the medium was replaced with $100 \mu 1$ of fresh medium containing $20 \mu \mathrm{l}$ of MTS solution and incubated for an additional $3 \mathrm{~h}$. Mitochondrial dehydrogenase enzymes of viable cells converted MTS tetrazolium into a colored formazan product. The optical density of samples was read at $492 \mathrm{~nm}$ in the DigiScan Microplate Reader (ASYS Hitech GmbH, Eugendorf, Austria).

Hoechst 33342 staining. Hoechst staining was performed to confirm the apoptotic profile as a result of morphological change in the nucleus in which Hoechst 33342 binds specifically to A-T base region in DNA and emits fluorescence. HEC-1A cells were seeded into 16-well chamber slides (Nalge Nunc, Naperville, IL, USA) at a density of 3000 cells/well in 
$200 \mu \mathrm{l}$ of the culture medium. After $24 \mathrm{~h}$, the medium was replaced with fresh FBS-free medium. After an additional $24 \mathrm{~h}$, the medium was replaced with fresh medium containing 2\% FBS and 10-6 M MZ-5-156. After $48 \mathrm{~h}$ incubation, HEC-1A cells were rinsed in PBS ( $\mathrm{pH} 7.4$ ) and fixed with 4\% paraformaldehyde in PBS at room temperature for $30 \mathrm{~min}$. Then, cells were rinsed in PBS twice and stained with Hoechst $33342(10 \mu \mathrm{g} / \mathrm{ml}$ in PBS $)$ for $3 \mathrm{~min}$. The specimens were mounted with Vectashield medium (Vector Laboratories Inc., Burlingame, CA, USA) and photographs were taken at magnification x200 under a fluorescent microscope (Olympus, Tokyo, Japan). The proportion of cells with nuclear fragmentation was calculated by counting the number of stained cells per $>200$ cells. Three different individuals made these observations 3 times each.

Flow cytomery. HEC-1A cells were seeded into a $10-\mathrm{cm}$ culture dish (Iwaki, Tokyo, Japan) at a density of $1 \times 10^{6}$ cells/ dish in $10 \mathrm{ml}$ of the culture medium. After $24 \mathrm{~h}$, the medium was replaced with fresh FBS-free medium. After an additional $24 \mathrm{~h}$, the medium was replaced with fresh medium containing $2 \% \mathrm{FBS}$ and $10^{-6} \mathrm{M} \mathrm{MZ}-5-156$, and cell culture was continued for a further 24,48 , or $72 \mathrm{~h}$. Then, the cells were harvested with trypsin $(0.05 \%)$ /EDTA $(0.02 \%)$, washed twice with ice-cold PBS ( $\mathrm{pH} 7.4$ ), and fixed with $70 \%$ ethanol at $-20^{\circ} \mathrm{C}$ overnight. After washing twice with ice-cold PBS, the cells were incubated in $0.25 \mathrm{mg} / \mathrm{ml}$ ribonuclease solution (Qiagen $\mathrm{GmbH}$, Hilden, Germany) for $30 \mathrm{~min}$ at $37^{\circ} \mathrm{C}$ and stained with $50 \mu 1 / \mathrm{ml}$ propidium iodide for $30 \mathrm{~min}$ on ice, followed by filtration through a 40- $\mu$ m nylon mesh (Becton Dickinson and Co.) to remove cell clumps. A total of 50,000 stained cells per treatment were analyzed in the EPICS XL Flow Cytometry (Beckman Couller, Inc., Fullerton, CA, USA). Sub-G1 phase represents low-molecular-weight DNA derived from apoptotic cells.

Western blotting. HEC-1A cells were seeded into 10-cm dish at a density of $1 \times 10^{6}$ cells/dish in $10 \mathrm{ml}$ of the culture medium. After $24 \mathrm{~h}$, the medium was replaced with fresh FBS-free medium. After an additional $24 \mathrm{~h}$, the medium was replaced with fresh medium containing 2\% FBS and $10^{-6} \mathrm{M} \mathrm{MZ-5-156.}$ After a further $48 \mathrm{~h}$, the cells were harvested with trypsin $(0.05 \%) /$ EDTA $(0.02 \%)$ and scraped into the lysis buffer containing $50 \mathrm{mM}$ Tris- $\mathrm{HCl}(\mathrm{pH} 8.0), 150 \mathrm{mM} \mathrm{NaCl}$, $0.02 \%$ sodium azide, $0.1 \%$ sodium dodecyl sulfate, $1 \%$ Nonidet P-40, and $0.5 \%$ sodium deoxycholate for $30 \mathrm{~min}$ on ice. Insoluble material was removed by centrifugation at $12,000 \mathrm{x} \mathrm{g}$, for $10 \mathrm{~min}$ at $4^{\circ} \mathrm{C}$. The supernatants were recovered, and the protein concentrations were measured using Bio-Rad protein assay reagent (Bio-Rad Lab., Hercules, CA, USA). Equivalent amounts of lysate protein $(30 \mu \mathrm{g})$ were subjected to $12 \%$ SDS-PAGE and electrophoretically transferred onto polyvinylidene difluoride membranes (Millipore Corp., Billerica, MA, USA) by using the Bio-Rad Semi-Dry Electrophoretic Transfer Cell. After blocking nonspecific binding sites by incubation for $1 \mathrm{~h}$ with Tris-buffered saline (25 mM Tris and $150 \mathrm{mM} \mathrm{NaCl}, \mathrm{pH}$ 7.6) containing $5 \%$ non-fat milk and $0.2 \%$ Tween-20, the membranes were blotted with the primary antibodies overnight at $4^{\circ} \mathrm{C}$. Rabbit polyclonal antibodies to phospho-p53 (Ser46) and cleaved

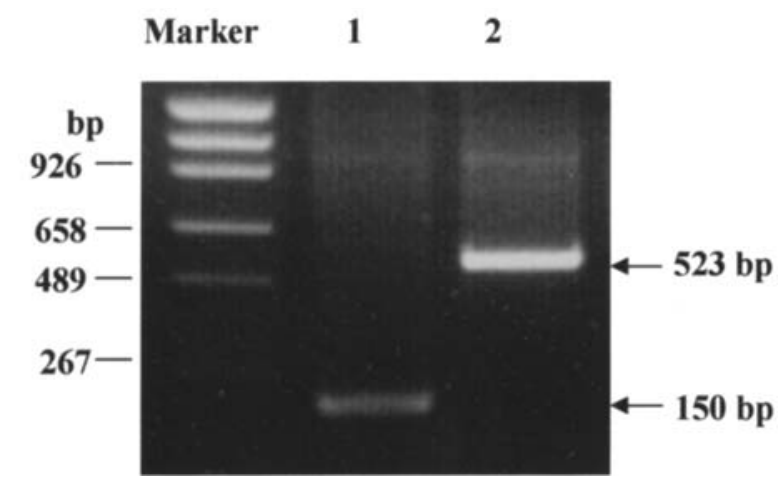

Figure 1. RT-PCR analysis of mRNA expression for GHRH (lane 1) and SV1 of GHRH-R (lane 2) in HEC-1A human endometrial cancer cell line. Sizes of PCR products, predicted on the basis of cDNA sequence, were $150 \mathrm{bp}$ for GHRH and 523 bp for SV1 of GHRH-R. The result is representative of three independent experiments.

caspase-3 and -9 were obtained from Cell Signaling Technology, Inc. (Beverly, MA, USA). Rabbit polyclonal antibody to Fas (C-20); mouse monoclonal antibodies to $\mathrm{Bcl}-2$ and caspase-8 (D-8); and goat polyclonal antibodies to p53AIP1 (p53-regulated Apoptosis-Inducing Protein 1) and actin were obtained from Santa Cruz Biotechnology, Inc. (Santa Cruz, CA, USA). Reactive proteins were detected with horseradish peroxidase-conjugated secondary antibodies (Cell Signaling Technology, Inc.) for $60 \mathrm{~min}$ at room temperature and developed with ECL Plus Western blotting detection reagents (Amersham Biosciences, Little Chalfont, UK). The images were scanned and analyzed by the fluorescence scanning system STORM (Molecular Dynamics, Inc., Sunnyvale, CA, USA). The values were normalized to actin levels and then expressed as a percentage of the control value.

Statistical analysis. The data represent the mean \pm SEM of at least three independent experiments. The statistical analysis was carried out by Mann-Whitney U test for paired comparison and One-way ANOVA with post hoc test for multiple comparisons by using StatView software (SAS Institute Inc., Cary, NC, USA). Repeated-measures ANOVA was applied for analysis of time course study of the effect of MZ-5-156 on HEC-1A cell viability. $\mathrm{P}<0.05$ was considered statistically significant.

\section{Results}

Expression of $m R N A$ for GHRH and SVI of GHRH-R in HEC1A cells. RT-PCR was performed to detect mRNA expression for GHRH and SV1 of GHRH-R in HEC-1A human endometrial cancer cell line. As shown in Fig. 1, an amplified product with the predicted size of $150 \mathrm{bp}$ for GHRH and a product with the predicted size of $523 \mathrm{bp}$ for SV1 of GHRH-R were observed in the cell line. Each PCR product was sequenced and confirmed to be identical to the sequence of GHRH and SV1 of GHRH-R, as previously described (32).

Effect of GHRH antagonist MZ-5-156 on the viability of HEC-1A cells. The effect of MZ-5-156 on HEC-1A cell viability was examined by MTS assay. MZ-5-156, at concentrations between $10^{-7}$ and $10^{-5} \mathrm{M}$, produced a dose-dependent 

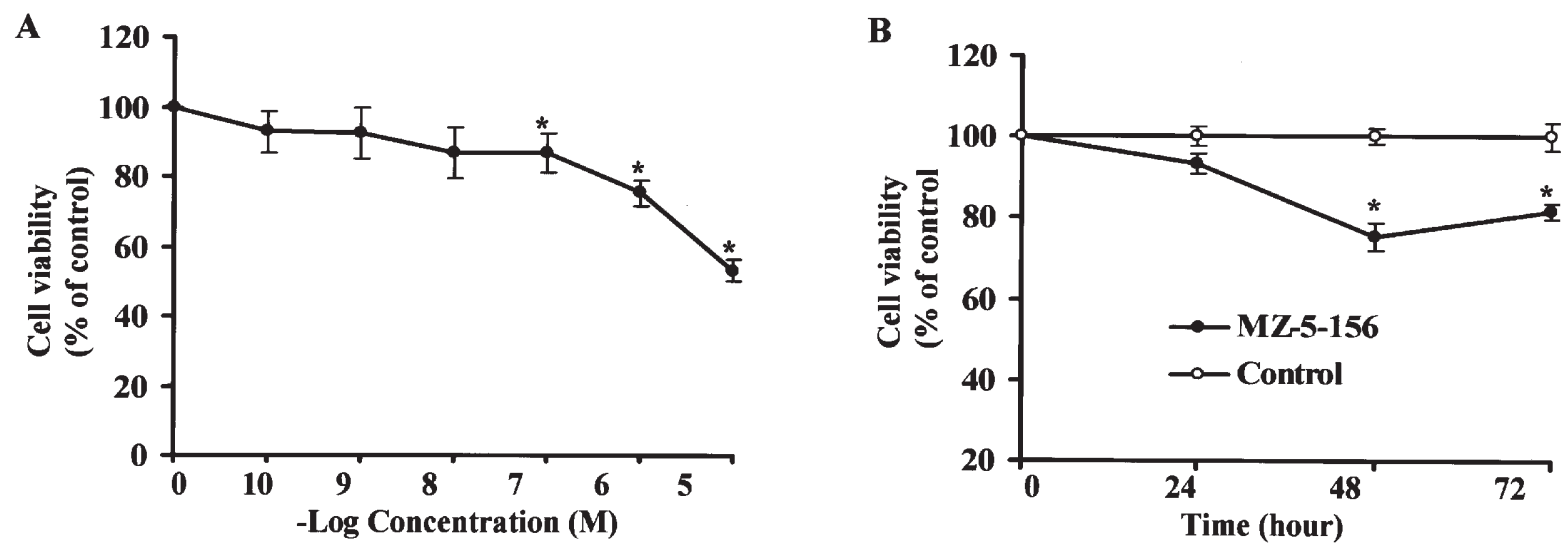

Figure 2. Effect of GHRH antagonist MZ-5-156 on the viability of cultured HEC-1A cells estimated by MTS assay. A, Treatment with MZ-5-156 at concentrations between $10^{-10}$ and $10^{-5} \mathrm{M}$ for $48 \mathrm{~h}$. Results are shown as the mean percentage of the untreated control at each time \pm SEM of 8 wells of three independent experiments. ${ }^{*} \mathrm{P}<0.05$ vs. control. B, Treatment with $10^{-6} \mathrm{M}$ MZ-5-156 for 24,48 , and $72 \mathrm{~h}$. Results are shown as the mean percentage of the untreated control at $0 \mathrm{~h} \pm$ SEM of 8 wells of five independent experiments. ${ }^{*} \mathrm{P}<0.05$ vs. $0 \mathrm{~h}$.
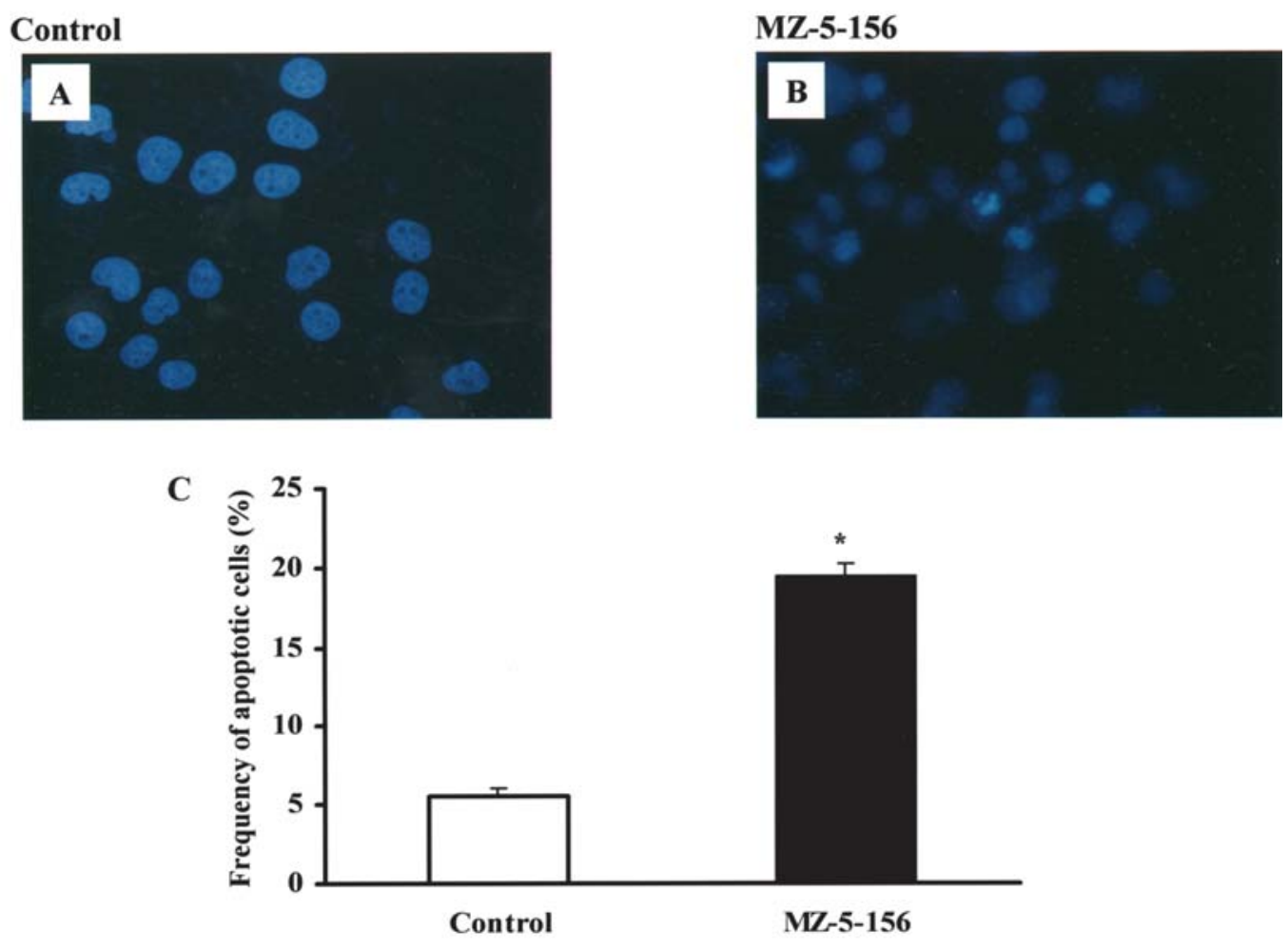

Figure 3. Hoechst 33342 staining of HEC-1A cells cultured with or without MZ-5-156 (magnification x200). A, Control. B, Treatment with MZ-5-156 (10-6 M) increased the rate frequency of cells with nuclear fragmentation at $48 \mathrm{~h}$. C, The frequency of cells with nuclear fragmentation by Hoechst 33342 staining was calculated by counting the number of stained cells per more than 200 cells. Results are shown as the mean \pm SEM of three independent experiments. $\mathrm{P}<0.05$ vs. control.

inhibition of HEC-1A cell viability after $48 \mathrm{~h}$ of treatment, with the maximal effect (reduction to $52.1 \pm 3.2 \%$ of the control) being observed at $10^{-5} \mathrm{M}$ (Fig. 2A). The cell viability was significantly reduced to $75.3 \pm 3.6 \%$ of $(0 \mathrm{~h})$ baseline after $48 \mathrm{~h}$ incubation with MZ-5-156 $\left(10^{-6} \mathrm{M}\right)$, and the antiproliferative effect was sustained up to $72 \mathrm{~h}$ (Fig. 2B). Control incubation at 24,48 , and $72 \mathrm{~h}$ did not result in significant loss of viability.

Induction of apoptosis by GHRH antagonist MZ-5-156 in HEC-1A cells. The effect of MZ-5-156 on the incidence of apoptotic cells was determined by Hoechst 33342 nuclear staining and flow cytometry in cultured HEC-1A cells. The apoptotic cells exhibiting shrunken nuclei, chromatin condensation, and nuclear fragmentation were recognized by Hoechst 33342 nuclear staining (Fig. 3B). The exact frequency of cells with nuclear fragmentation by Hoechst 33342 staining is shown in Fig. 3C. The percentage of dead cells was significantly increased after $48 \mathrm{~h}$ incubation with $10^{-6}$ M MZ-5-156 (19.4 $\pm 0.8 \%$; $<<0.05$ vs. control) compared with that of the control $(5.6 \pm 0.5 \%)$. Fig. $4 \mathrm{~A}$ is a representative 


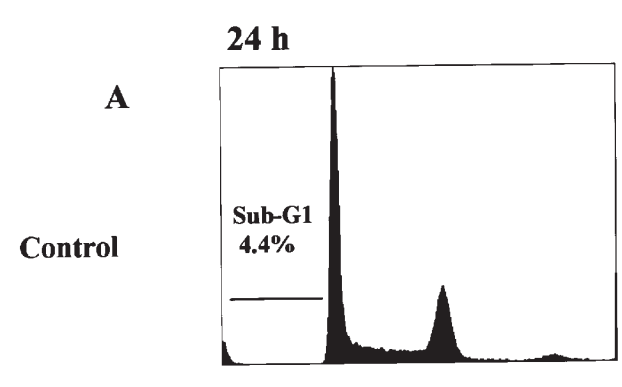

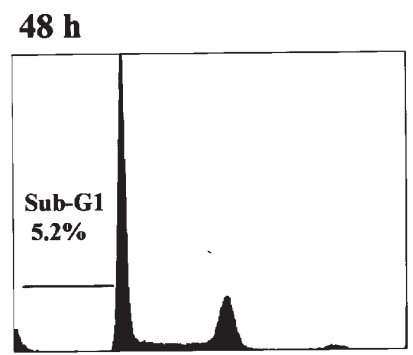

$72 \mathrm{~h}$
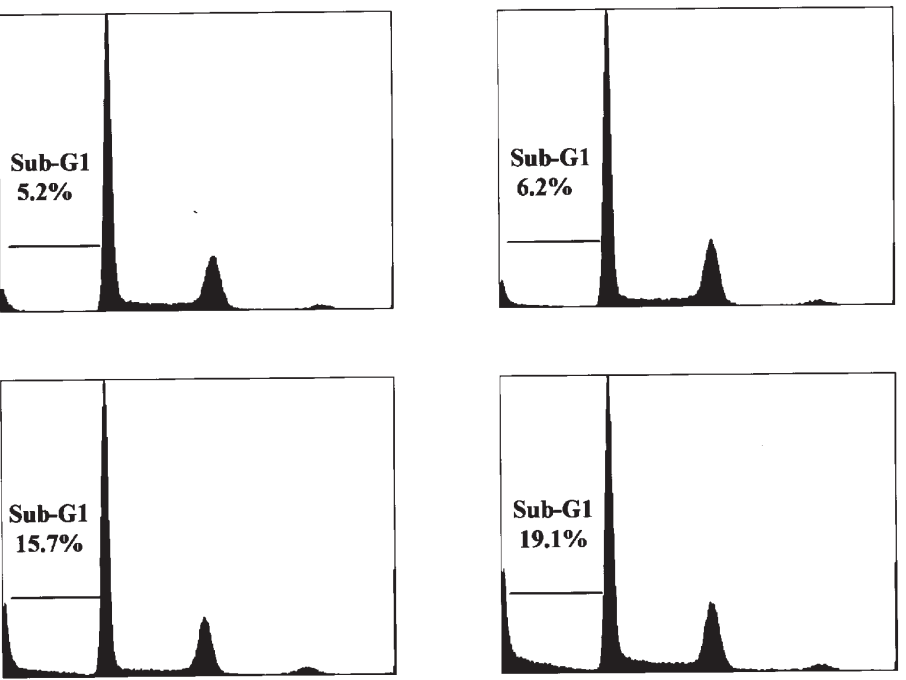

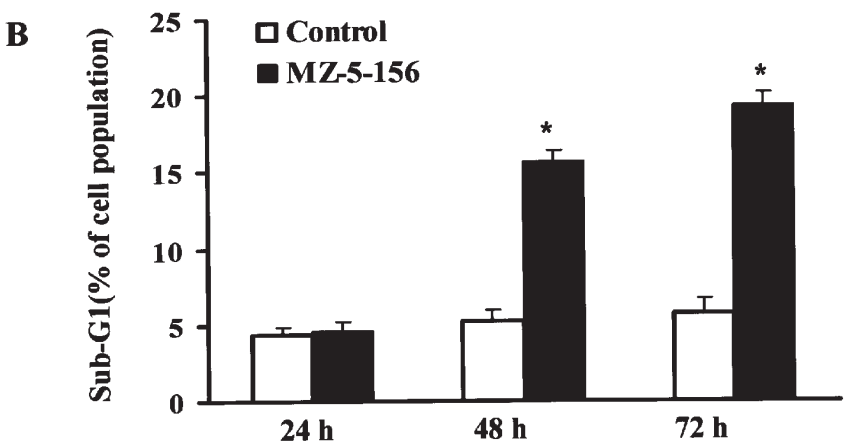

Figure 4. DNA histograms of GHRH antagonist MZ-5-156-treated HEC-1A cells. Cells were incubated with or without MZ-5-156 (10-6 M) for 24, 48, and 72 h, and then analyzed by flow cytometry. Sub-G1 indicates an apoptotic cell fraction. A, The result of flow cytometric analysis is representative of six independent experiments. B, Effects of MZ-5-156 on the proportion of Sub-G1 phase. Results are shown as the mean \pm SEM of six independent experiments. ${ }^{*}<0.05$ vs. control.
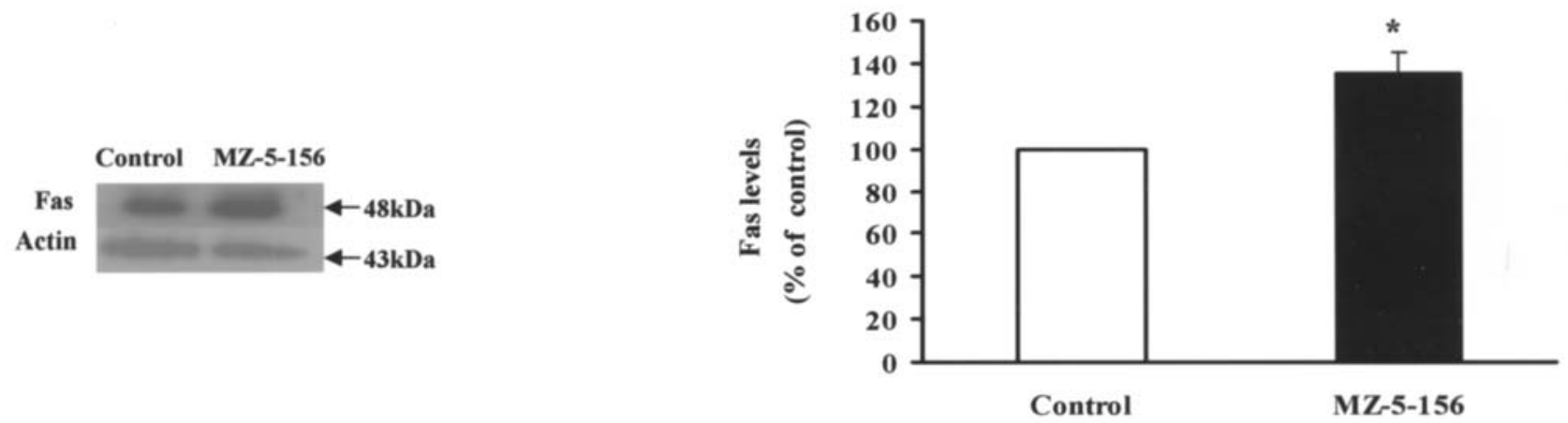

Figure 5. Effect of GHRH antagonist MZ-5-156 on the expression of protein levels of Fas in HEC-1A cells. Cells were incubated with or without MZ-5-156 $\left(10^{-6} \mathrm{M}\right)$ for $48 \mathrm{~h}$. Protein extracts were subjected to SDS-PAGE followed by Western blot analysis of protein levels of Fas. Results in the left panel are representative of four independent experiments. Results in the right panel show quantitative analysis of Fas levels and are presented as the mean percentage of the untreated control \pm SEM of four independent experiments. ${ }^{*} \mathrm{P}<0.05$ vs. control.

result of three independent experiments showing the proportion of sub-G1 phase, an apoptotic cell fraction. As shown in Fig. 4B, flow cytometric analysis revealed that the proportion of sub-G1 phase was significantly increased by the addition of $10^{-6} \mathrm{M} \mathrm{MZ}-5-156(15.7 \pm 0.7 \%$; $\mathrm{P}<0.05)$, compared with that for the control $(5.2 \pm 0.7 \%)$ at $48 \mathrm{~h}$ of treatment. At $72 \mathrm{~h}$, the proportion of sub-G1 phase was further increased to $19.1 \pm 0.7 \%$ $(\mathrm{P}<0.05)$, compared with the control value of $6.2 \pm 0.7 \%$.
Effect of GHRH antagonist MZ-5-156 on the expression levels of apoptosis-related proteins in HEC-Al cells. We examined the protein levels of apoptosis-related proteins, including Fas, phospho-p53 (Ser46), p53AIP1, Bcl-2, and caspase-3, -8, and -9 in HEC-1A cells exposed to $10^{-6} \mathrm{M} \mathrm{MZ}-5-156$ for $48 \mathrm{~h}$, by using Western blot analysis. Fig. 5 shows that the expression level of Fas was significantly increased to $135.3 \pm 9.5 \%$ of the control ( $\mathrm{P}<0.05$ vs. control). As depicted in Fig. 6, the 

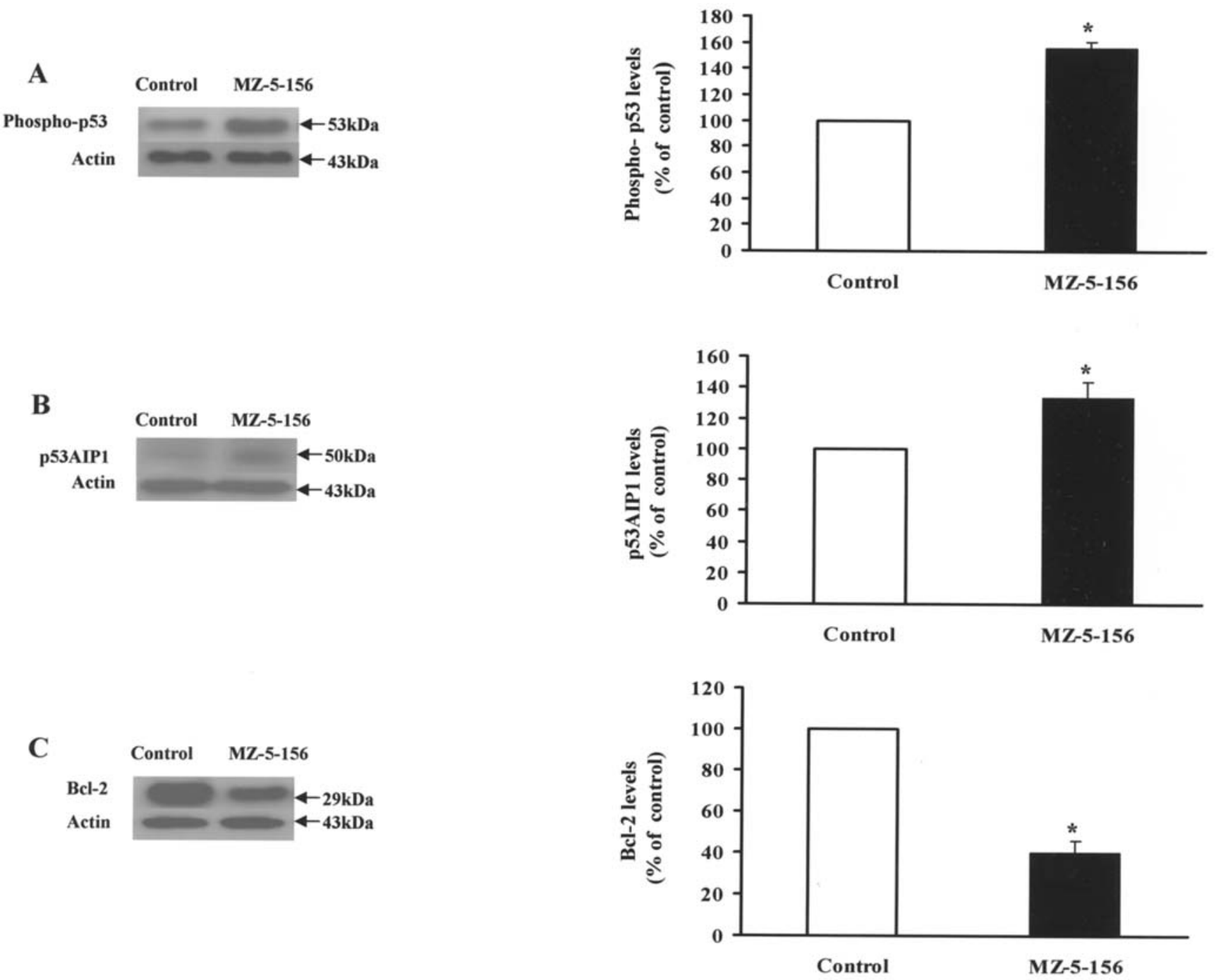

Figure 6. Effect of GHRH antagonist MZ-5-156 on the expression of protein levels of phospho-p53 (Ser46), p53AIP1, and Bcl-2 in HEC-1A cells. Cells were incubated with or without MZ-5-156 $\left(10^{-6} \mathrm{M}\right)$ for $48 \mathrm{~h}$. Protein extracts were subjected to SDS-PAGE followed by Western blot analysis of protein levels of (A) phospho-p53 (Ser46), (B) p53AIP1, and (C) Bcl-2. Results in the left panels are representative of four independent experiments. Results in the right panels show quantitative analysis of each protein level and are presented as the mean percentage of the untreated control \pm SEM of four independent experiments. ${ }^{*} \mathrm{P}<0.05$ vs. control.

expression levels of phospho-p53 (Ser46) and P53AIP1 were significantly increased to $155.4 \pm 5.2$ and $133.2 \pm 10.6 \%$, respectively, whereas $\mathrm{Bcl}-2$ levels were decreased to $40.0 \pm 6.1 \%$, compared with the control value $(\mathrm{P}<0.05)$. Fig. 7 (left), illustrates representative results, exhibiting the $17-\mathrm{kDa}$ cleavage fragments of activated caspase-3, the $20-\mathrm{kDa}$ cleavage fragments of activated caspase- 8 , and the $17-\mathrm{kDa}$ cleavage fragments of activated caspase-9, respectively. As shown in Fig. 7 (right), the expression levels of cleaved caspase-3, -8 , and -9 were significantly up-regulated to $143.8 \pm 13.9,164.7 \pm 10.5$, and $182.0 \pm 23.5 \%$ of the control, respectively.

\section{Discussion}

Evidence summarized $(3,4)$ indicates that GHRH acts as an autocrine/paracrine regulator of cancer cell proliferation and that SV1 of GHRH-R is the main functional receptor responsible for mediating the effects of GHRH and its antagonists in tumors. In the present study, using RT-PCR, we demonstrated that mRNA for GHRH and SV1 of GHRH-R is expressed in HEC-1A human endometrial cancer cell line, suggesting that an autocrine/paracrine GHRH loop may be present in the cell line and participate in the regulation of cell growth. All of the SVs of GHRH-R have a retained intronic sequence at the 5'-end but lack the first three exons $(10,11)$. The lack of the first three exons in SV1 results in a tumoral receptor protein, in which most of the large NH2-terminal extracellular domain, characteristic of the pituitary receptor, is truncated. Thus, the mRNA for SV1 encodes a functional receptor protein that binds GHRH and its analogs but is different from the pituitary GHRH-R $(10,11)$. The participation of SV1 in cell proliferation signaling was proven by several studies (18-20). NIH 3T3 mouse fibroblast cells transfected with SV1 displayed augmented sensitivity and mitogenic responses to GHRH analogs, compared to the untransfected cells (18). Besides its ligand-dependent activation, a ligand-independent constitutive activation of SV1 has been demonstrated, by using an anti-sense RNAbased approach on HEC-1A cells, which express SV1 (19). 


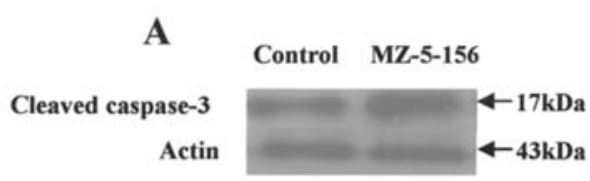

B
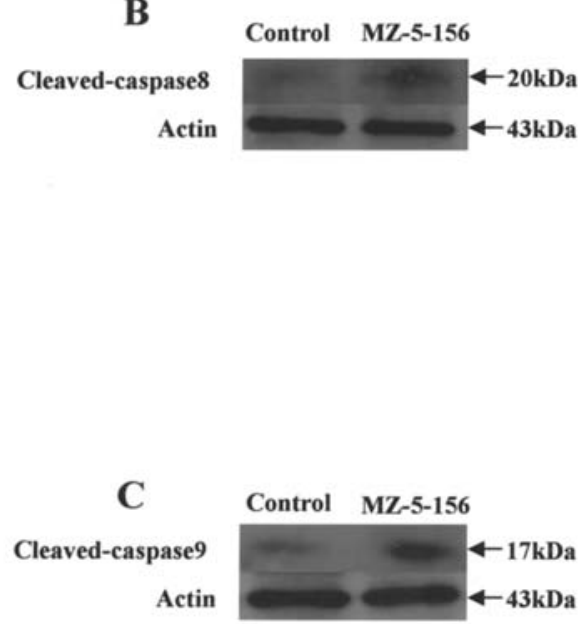
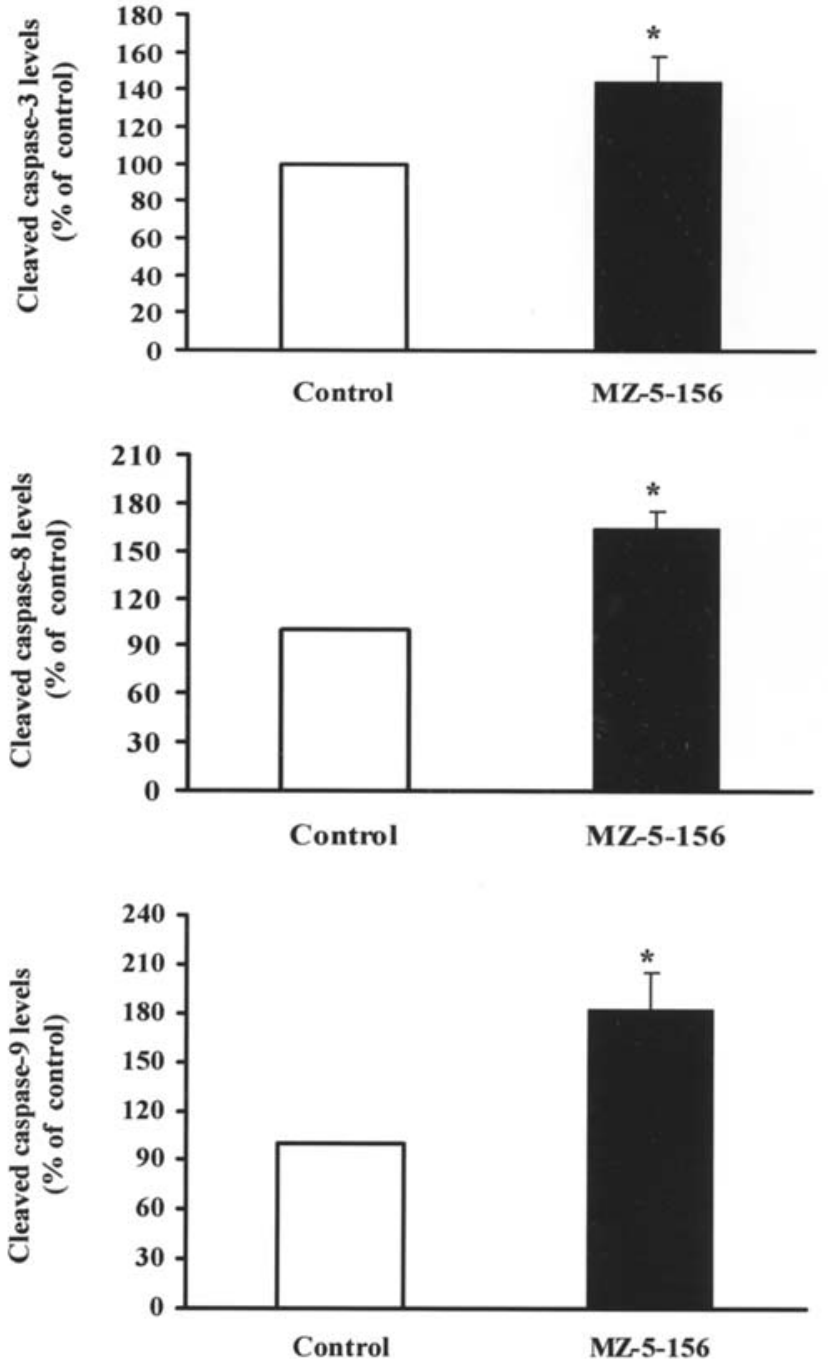

Figure 7. Western blot analysis of protein levels of cleaved caspase-3, -8, and -9 in HEC-1A cells treated with or without MZ-5-156 (10-6 M) for 48 h. Cell protein lysates were analyzed by immunoblotting with anti-cleaved caspase-3, anti-caspase- 8 , and anti-cleaved caspase- 9 antibody, which recognizes active cleavage fragments of (A) $17 \mathrm{kDa}$, (B) $20 \mathrm{kDa}$, and (C) $17 \mathrm{kDa}$, respectively. Results in the left panels are representative films exhibiting bands for active forms of caspases with corresponding actin bands. Results in the right panels show quantitative analysis of caspase-3, -8 , and -9 cleavage into active forms and are presented as the mean percentage of the untreated control $\pm \mathrm{SEM}$ of four independent experiments. * $\mathrm{P}<0.05$ vs. control.

The ablation of SV1 reduced the rate of cell proliferation in the absence of exogenous GHRH and decreased their sensitivity to GHRH (19). In MCF-7 human breast cancer cells transfected with the full-length GHRH-R or its SV1, the ligand-independent activity of SV1 was greater than that of GHRH-R and the expression of SV1 appeared to confer oncogenic activity (20). By using real-time PCR, mRNA for the pituitary type of GHRH-R was detected in various human cancers for the first time (32), which confirms and extends the concept that GHRH and its receptors play an important role in the pathophysiology of human cancers (4).

Current studies have shown that GHRH antagonist MZ5-156 directly inhibits the growth of human ovarian, breast, prostate, and pancreatic cancers and non-Hodgkin's lymphomas $(6,17,21,29,30)$. The present in vitro study demonstrated that MZ-5-156 exerts a dose-dependent antiproliferative action in HEC-1A cells, as determined by MTS assay, and induces apoptosis in these cells in a p53-dependent manner, as documented by Hoechst 33342 staining, flow cytometric analysis, and Western blotting. Our study indicates that apoptosis may be one way of explaining the mechanisms of the antiproliferative effect of MZ-5-156 on HEC-1A cells. Although several studies showed that the antiproliferative activity induced by GHRH antagonists might be mediated by stimulation of apoptotic cell death (24-27), the exact apoptotic pathway remained to be elucidated.

Upon exposure to genotoxic stress, the tumor suppressor p53 controls multiple downstream targets that regulate variable cellular outcomes such as cell-cycle arrest, induction of apoptosis, and maintenance of genetic stability by modulation of DNA repair, replication, and recombination machinery $(33,34)$. So far, two separate apoptotic pathways have been described for p53-dependent apoptosis (34). The extrinsic, death-receptor pathway triggers the activation of caspase cascade, and the intrinsic, mitochondrial pathway shifts the balance in the Bcl-2 family towards the pro-apoptotic 
members, leading to caspase-mediated apoptosis (34). The extrinsic pathway involves engagement of the death receptors that belong to the tumor necrosis factor (TNF) receptor superfamily and, through the formation of the death-inducing signaling complex (DISC), leads to a cascade of activation of caspases, including caspase- 8 and caspase- 3 , which in turn induce apoptosis. In the extrinsic pathway, activated caspase- 8 also induces mitochondrial apoptotic signaling through Bid which is a p53 target (34). p53 can activate the extrinsic apoptotic pathway through the induction of genes encoding transmembranous proteins $(35,36)$. Among p53downstream genes, Fas (APO-1/CD95), a member of TNF receptor superfamily, is a key component of the extrinsic death pathway $(37,38)$. The present study showed that the protein levels of Fas, and caspase- 8 and -3 were increased by treatment with MZ-5-156 in HEC-1A cells, indicating that the extrinsic pathway could be enhanced by GHRH antagonists.

The intrinsic pathway is triggered in response to DNA damage and is associated with mitochondrial depolarization and release of cytochrome $c$ from the mitochondria. Cytosolic cytochrome $c$ induces formation of the apoptosome by stimulating oligomerization of the adapter protein, apoptotic protease-activating factor 1 (Apaf-1) and, consequently, recruitment of the initiator caspase-9 (39). As a result, activated caspase- 9 can then directly cleave and activate caspase- 3 . The intrinsic apoptotic pathway is dominated by the Bcl-2 family of proteins which controls the release of cytochrome $c$ from the mitochondria (34). Bcl-2, a mitochondrial protein, inhibits apoptotic process and promotes cell survival. It is known that Bcl-2 directly or indirectly, prevents the release of cytochrome $c$ from the mitochondria $(40,41)$. Overexpression of Bcl-2 can block p53-dependent dissipation of the mitochondrial membrane potential $(\Delta \Psi \mathrm{m})(40,41)$. Recently, a new p53-dependent pro-apoptotic gene, p53AIP1, was identified (42). When p53 is phosphorylated at Ser46 in response to severe DNA damage, the expression of p53AIP1, a component of the mitochondrial membrane, is induced and followed by depolarization of mitochondrial membrane and sequentially by the release of cytochrome $c$ from the mitochondria (43). Ectopic expression of p53AIP1 in the mitochondria induced dissipation of the mitochondrial $\Delta \Psi \mathrm{m}$ and release of cytochrome $c$ from the mitochondria (43). Interaction between p53AIP1 and $\mathrm{Bcl}-2$ might regulate the mitochondrial $\Delta \Psi \mathrm{m}$ by balancing positive and negative effects (43). In the present study, the protein levels of phospho-p53 (Ser46), p53AIP1, and caspase-8, -9, and -3 were increased, and Bcl-2 levels were decreased by treatment with MZ-5-156 in HEC-1A cells, indicating that the intrinsic pathway could also be enhanced by GHRH antagonists.

In conclusion, our study demonstrates that GHRH antagonist MZ-5-156 inhibits directly the growth of HEC-1A human endometrial cancer cells, which express mRNA for GHRH and SV1 of GHRH-R, presumably through the induction of p53-dependent apoptosis coupled with the upregulation of Fas, phospho-p53 (Ser46), p53AIP1, and caspase- $8,-9$, and -3 , and the down-regulation of Bcl-2. The p53-dependent apoptosis induced by MZ-5-156 can be mediated through both death-receptor pathway and mitochondrial pathway. These results suggest that GHRH antagonists, such as MZ-5-156, are potentially useful in the treatment of endometrial cancer, but further studies followed by clinical trials are necessary to validate this approach.

\section{Acknowledgements}

This study was supported by a Grant-in-Aid for Scientific Research from the Ministry of Education, Science and Culture.

\section{References}

1. Jemal A, Siegel R, Ward E, Murray T, Xu J and Thun MJ: Cancer statistics, 2007. CA Cancer J Clin 57: 43-66, 2007.

2. Amant F, Moerman P, Neven P, Timmerman D, van Limbergen E and Vergote I: Endometrial cancer. Lancet 366: 491-505, 2005.

3. Kiaris H, Schally AV and Kalofoutis A: Extrapituitary effects of the growth hormone-releasing hormone. Vitam Horm 70: 1-24, 2005.

4. Schally AV and Varga JL: Antagonists of growth hormonereleasing hormone in oncology. Comb Chem High Throughput Screen 9: 163-170, 2006.

5. Furstenberger $\mathrm{G}$ and Senn HJ: Insulin-like growth factors and cancer. Lancet Oncol 3: 298-302, 2002.

6. Chatzistamou I, Schally AV, Varga JL, Groot K, Armatis P, Busto R and Halmos G: Antagonists of growth hormonereleasing hormone and somatosatin analog RC-160 inhibit the growth of OV-1063 human epithelial ovarian cancer cell line xenografted into nude mice. J Clin Endocrinol Metab 86: 2144-2152, 2001.

7. Engel JB, Keller G, Schally AV, Toller GL, Groot K, Havt A, Armatis P, Zarandi M, Varga JL and Halmos G: Inhibition of growth of experimental human endometrial cancer by an antagonist of growth hormone-releasing hormone. J Clin Endocrinol Metab 90: 3614-3621, 2005.

8. Kiaris H, Schally AV, Varga JL, Groot K and Armatis P: Growth hormone-releasing hormone: an autocrine growth factor for small cell lung carcinoma. Proc Natl Acad Sci USA 96: 14894-14898, 1999.

9. Chatzistamou I, Schally AV, Varga JL, Groot K, Busto R, Armatis $\mathrm{P}$ and Halmos $\mathrm{G}$ : Inhibition of growth and metastases of MDA-MB-435 human estrogen-independent breast cancers by an antagonist of growth hormone-releasing hormone. Anticancer Drugs 12: 761-768, 2001.

10. Rekasi Z, Czompoly T, Schally AV and Halmos G: Isolation and sequencing of cDNAs for splice variants of growth hormonereleasing hormone receptors from human cancers. Proc Natl Acad Sci USA 97: 10561-10566, 2000.

11. Halmos G, Schally AV, Varga JL, Plonowski A, Rekasi Z and Czompoly T: Human renal cell carcinoma expresses distinct binding sites for growth hormone-releasing hormone. Proc Natl Acad Sci USA 97: 10555-10560, 2000.

12. Halmos G, Schally AV, Czompoly T, Krupa M, Varga JL and Rekasi Z: Expression of growth hormone-releasing hormone and its receptor splice variants in human prostate cancer. J Clin Endocrinol Metab 87: 4707-4714, 2002.

13. Busto R, Schally AV, Varga JL, Garcia-Fernandez MO, Groot K, Armatis P and Szepeshazi K: The expression of growth hormonereleasing hormone (GHRH) and splice variants of its receptor in human gastroenteropancreatic carcinomas. Proc Natl Acad Sci USA 99: 11866-11871, 2002

14. Plonowski A, Schally AV, Busto R, Krupa M, Varga JL and Halmos G: Expression of growth hormone-releasing hormone $(\mathrm{GHRH})$ and splice variants of GHRH receptors in human experimental prostate cancers. Peptides 23: 1127-1133, 2002.

15. Szereday Z, Schally AV, Varga JL, Kanashiro CA, Hebert F, Armatis P, Groot K, Szepeshazi K, Halmos G and Busto R: Antagonists of growth hormone-releasing hormone inhibit the proliferation of experimental non-small cell lung carcinoma. Cancer Res 63: 7913-7919, 2003.

16. Garcia-Fernandez MO, Schally AV, Varga JL, Groot K and Busto R: The expression of growth hormone-releasing hormone (GHRH) and its receptor splice variants in human breast cancer lines; the evaluation of signaling mechanisms in the stimulation of cell proliferation. Breast Cancer Res Treat 77: 15-26, 2003. 
17. Keller G, Schally AV, Groot K, Toller GL, Havt A, Koster F, Armatis P, Halmos G, Zarandi M, Varga JL and Engel JB: Effective treatment of experimental human non-Hodgkin's lymphomas with antagonists of growth hormone-releasing hormone. Proc Natl Acad Sci USA 102: 10628-10633, 2005.

18. Kiaris H, Schally AV, Busto R, Halmos G, Artavanis-Tsakonas S and Varga JL: Expression of a splice variant of the receptor for GHRH in 3T3 fibroblasts activates cell proliferation responses to GHRH analogs. Proc Natl Acad Sci USA 99: 196-200, 2002.

19. Kiaris H, Chatzistamou I, Schally AV, Halmos G, Varga JL, Koutselini $\mathrm{H}$ and Kalofoutis A: Ligand-dependent and independent effects of splice variant 1 of growth hormonereleasing hormone receptor. Proc Natl Acad Sci USA 100: 9512-9517, 2003.

20. Barabutis N, Tsellou E, Schally AV, Kouloheri S, Kalofoutis A and Kiaris H: Stimulation of proliferation of MCF-7 breast cancer cells by a transfected splice variant of growth hormonereleasing hormone receptor. Proc Natl Acad Sci USA 104: 5575-5579, 2007

21. Csernus V, Schally AV and Groot K: Antagonistic analogs of growth hormone releasing hormone (GHRH) inhibit cyclic AMP production of human cancer cell lines in vitro. Peptides 20: 843-850, 1999

22. Rekasi Z, Varga JL, Schally AV, Plonowski A, Halmos G Csernus B, Armatis P and Groot K: Antiproliferative actions of growth hormone-releasing hormone antagonists on MiaPaCa-2 human pancreatic cancer cells involve cAMP independent pathways. Peptides 22: 879-886, 2001.

23. Kanashiro CA, Schally AV, Zarandi M, Hammann BD and Varga JL: Suppression of growth of H-69 small cell lung carcinoma by antagonists of growth hormone releasing hormone and bombesin is associated with an inhibition of protein kinase $\mathrm{C}$ signaling. Int J Cancer 112: 570-576, 2004.

24. Rekasi Z, Czompoly T, Schally AV, Boldizsar F, Varga JL, Zarandi M, Berki T, Horvath RA and Nemeth P: Antagonist of growth hormone-releasing hormone induces apoptosis in $\mathrm{LNCaP}$ human prostate cancer cells through a $\mathrm{Ca}^{2+}$-dependent pathway. Proc Natl Acad Sci USA 102: 3435-3440, 2005

25. Szepeshazi K, Schally AV, Armatis P, Groot K, Hebert F, Feil A, Varga JL and Halmos G: Antagonists of GHRH decrease production of GH and IGF-I in MXT mouse mammary cancers and inhibit tumor growth. Endocrinology 142: 4371-4378, 2001.

26. Szepeshazi K, Schally AV, Groot K, Armatis P, Halmos G, Herbert F, Szende B, Varga JL and Zarandi M: Antagonists of growth hormone-releasing hormone (GH-RH) inhibit IGF-II production and growth of HT-29 human colon cancers. Br J Cancer 82: 1724-1731, 2000.

27. Zeitler P and Siriwardana G: Antagonism of endogenous growth hormone-releasing hormone leads to reduced proliferation and increased apoptosis in MDA231 breast cancer cells. Endocrine 18: 85-90, 2002.

28. Zarandi M, Kovacs M, Horvath JE, Toth K, Halmos G, Groot K, Nagy A, Kele Z and Schally AV: Synthesis and in vitro evaluation of new potent antagonists of growth hormonereleasing hormone (GH-RH). Peptides 18: 423-430, 1997.
29. Lamharzi N, Schally AV, Koppan M and Groot K: Growth hormone-releasing hormone antagonist MZ-5-156 inhibits growth of DU-145 human androgen-independent prostate carcinoma in nude mice and suppresses the levels and mRNA expression of insulin-like growth factor II in tumors. Proc Natl Acad Sci USA 95: 8864-8868, 1998.

30. Szepeshazi K, Schally AV, Groot K, Armatis P, Hebert F and Halmos G: Antagonists of growth hormone-releasing hormone (GH-RH) inhibit in vivo proliferation of experimental pancreatic cancers and decrease IGF-II levels in tumours. Eur J Cancer 36: $128-136,2000$.

31. Kuramoto H, Tamura S and Notake Y: Establishment of a cell line of human endometrial adenocarcinoma in vitro. Am J Obstet Gynecol 114: 1012-1019, 1972.

32. Havt A, Schally AV, Halmos G, Varga JL, Toller GL, Horvath JE, Szepeshazi K, Koster F, Kovitz K, Groot K, Zarandi M and Kanashiro CA: The expression of the pituitary growth hormonereleasing hormone receptor and its splice variants in normal and neoplastic human tissues. Proc Natl Acad Sci USA 102: 17424-17429, 2005

33. Bargonetti J and Manfredi JJ: Multiple roles of the tumor suppressor p53. Curr Opin Oncol 14: 86-91, 2002.

34. Haupt S, Berger M, Goldberg Z and Haupt Y: Apoptosis - the p53 network. J Cell Sci 116: 4077-4085, 2003.

35. Owen-Schaub LB, Zhang W, Cusack JC, Angelo LS, Santee SM, Fujiwara T, Roth JA, Deisseroth AB, Zhang WW, Kruzel E and Radinsky R: Wild-type human p53 and a temperature-sensitive mutant induce Fas/APO-1 expression. Mol Cell Biol 15: 3032-3040, 1995.

36. Muller M, Wilder S, Bannasch D, Israeli D, Lehlbach K, LiWeber M, Friedman SL, Galle PR, Stremmel W, Oren M and Krammer PH: p53 activates the CD95 (APO-1/Fas) gene in response to DNA damage by anticancer drugs. J Exp Med 188: 2033-2045, 1998.

37. Nagata S: Apoptosis by death factor. Cell 88: 355-365, 1997.

38. Krammer PH: CD95's deadly mission in the immune system. Nature 407: 789-795, 2000

39. Cecconi F: Apaf1 and the apoptotic machinery. Cell Death Differ 6: 1087-1098, 1996

40. Chiou SK, Rao L and White E: Bcl-2 blocks p53-dependent apoptosis. Mol Cell Biol 14: 2556-2563, 1994.

41. Yang J, Liu X, Bhalla K, Kim CN, Ibrado AM, Cai J, Peng TI, Jones DP and Wang X: Prevention of apoptosis by Bcl-2: release of cytochrome c from mitochondria blocked. Science 275: 1129-1132, 1997.

42. Oda K, Arakawa H, Tanaka T, Matsuda K, Tanikawa C, Mori T, Nishimori H, Tamai K, Tokino T, Nakamura Y and Taya Y: p53AIP1, a potential mediator of p53-dependent apoptosis, and its regulation by Ser-46-phosphorylated p53. Cell 102: 849-862, 2000 .

43. Matsuda K, Yoshida K, Taya Y, Nakamura K, Nakamura Y and Arakawa H: p53AIP1 regulates the mitochondrial apoptotic pathway. Cancer Res 62: 2883-2889, 2002. 